\title{
Structured Perovskite-Based Oxides: Use in the Combined Methane Reforming
}

\author{
Adriana García ${ }^{1}$, Norymar Becerra ${ }^{1}$, Luis García ${ }^{1}$, Ini Ojeda ${ }^{1}$, Estefanía López ${ }^{1}$, \\ Carmen M. López ${ }^{2}$, Mireya R. Goldwasser ${ }^{2}$ \\ ${ }^{1}$ Facultad de Ingeniería, Universidad Central de Venezuela, Caracas, Venezuela \\ ${ }^{2}$ Facultad de Ciencias, Universidad Central de Venezuela, Caracas, Venezuela \\ E-mail:adriana.ucv@gmail.com \\ Recieved July 16, 2011; revised August 10, 2011; accepted August 30, 2011
}

\begin{abstract}
The behavior of metallic structured perovskite-based catalysts was evaluated in the combined methane reforming reaction with $\mathrm{CO}_{2}-\mathrm{O}_{2}$. The reaction conditions were established by varying the reaction temperature and reactor input composition in the range of 650 to $850^{\circ} \mathrm{C}$ and $\mathrm{CH}_{4} / \mathrm{CO}_{2}$ ratio 1 to 5, respectively. The results of the catalytic tests at $750^{\circ} \mathrm{C}$ showed a positive effect of the metallic structure, producing higher conversions and $\mathrm{H}_{2} / \mathrm{CO}$ ratios in the products compare to that obtained with the powder catalyst.
\end{abstract}

Keywords: Methane Reforming, Perovskites, Syngas Production, Structured Catalysts

\section{Introduction}

Catalytic steam methane reforming (SMR) is the principal commercial technology for syngas production [1-3]. This process has the advantage of using natural gas as feedstock, which is an abundant material available at low cost, in addition to producing a high $\mathrm{H}_{2} / \mathrm{CO}$ ratio, according Equation (1):

$$
\mathrm{CH}_{4}+\mathrm{H}_{2} \mathrm{O} \rightarrow \mathrm{CO}+3 \mathrm{H}_{2} \quad\left(\Delta \mathrm{H}_{\mathrm{r}}=206 \mathrm{~kJ} / \mathrm{mol}\right)
$$

Since this reaction (Equation (1)) is highly endothermic, it is necessary to use high temperature and pressures. These severe reaction conditions cause catalyst deactivation due to carbon deposits on the catalyst surface. The possibility of combining exothermic oxidation of methane (Equations (2) and (3)) with the SMR has emerged as an alternative to overcome this disadvantage. The purpose is to provide the heat required by the endothermic reactions, from the heat released by the exothermic reactions [4-6]. In the same way, methane reforming with carbon dioxide, known as dry methane reforming (DMR), to produce syngas with a $\mathrm{H}_{2} / \mathrm{CO}$ ratio equal to unity (Equation (4)), is one of the methods that utilize one the major greenhouse contributor. There are abundant reserves of natural gas with significant proportions of $\mathrm{CO}_{2}$, which can serve as raw material to the process of dry methane reforming. The combination of DMR and dry methane oxidation (Equations (2) and (3)) is known as combined methane reforming. Recently this subject has been a matter of increasing interest as observed by the large number of publications [7-10].

$$
\begin{aligned}
& \mathrm{CH}_{4}+\frac{1}{2} \mathrm{O}_{2} \longrightarrow \mathrm{CO}+2 \mathrm{H}_{2}\left(\Delta \mathrm{H}_{\mathrm{r}}=-36 \mathrm{~kJ} / \mathrm{mol}\right) \\
& \mathrm{CH}_{4}+2 \mathrm{O}_{2} \longrightarrow \mathrm{CO}_{2}+2 \mathrm{H}_{2} \mathrm{O}\left(\Delta \mathrm{H}_{\mathrm{r}}=-802 \mathrm{~kJ} / \mathrm{mol}\right) \\
& \mathrm{CH}_{4}+\mathrm{CO}_{2} \longrightarrow 2 \mathrm{CO}+2 \mathrm{H}_{2}\left(\Delta \mathrm{H}_{\mathrm{r}}=264 \mathrm{~kJ} / \mathrm{mol}\right)
\end{aligned}
$$

Combination of exothermic and endothermic reactions is a very important accomplishment to obtain temperature compensation of the process. A new approach presented by several authors is based in the use of structured metal carriers instead of random ceramic supports. The new carriers with open structures allow achievement of higher heat transfer coefficients and lower pressures drop [11-13].

Oxygen addition to DMR reduces carbon deposition on the catalyst surface and increases methane conversion. Similarly, the type of catalyst used could also inhibit coke formation. In this sense, the use of perovskite type oxides emerge as an alternative since after reduction it is possible to produce highly disperse metallic particles, diminishing deactivation of the catalyst by suppressing the coke forming reactions [14-18]. However, the refractory character of heat conduction in perovskite oxides could be disadvantageous to the combined processes. The use of metallic structures as carriers of catalysts has 
arisen as a way to achieve a better heat transfer in the catalytic bed.

In this work, we present the results of combined methane reforming with $\mathrm{CO}_{2}$ and $\mathrm{O}_{2}$, using metallic structures similar to a commercial packing, as supports for $\mathrm{LaNiO}_{3}$ perovskite-type oxide. The performance of these systems is compared to the unsupported catalyst.

\section{Experimental}

\subsection{Catalyst Preparation and Characterization}

The studied $\mathrm{LaNiO}_{3}$ perovskite-type oxide was synthesized using a modification of the citrate sol-gel method [19]. Adequate amounts of the cationic precursors (La and $\mathrm{Ni}$ ) were dissolved under vigorous stirring in a solution of citric acid (Riedel-de Haen) with an equal proportion of ethylene glycol (Riedel-de Haen) as the organic polydentate ligand. The formed gel was subjected to evaporation at $80^{\circ} \mathrm{C}$; then the gel was heating to $200^{\circ} \mathrm{C}$ at a rate of $0.5^{\circ} \mathrm{C} / \mathrm{min}$. At this temperature a flow of oxygen was incorporated and the heating was continued to $400^{\circ} \mathrm{C}$ at a rate of $1{ }^{\circ} \mathrm{C} / \mathrm{min}$.

Solids were characterized by several techniques such as X-ray diffraction (XRD) using a Bruker AXS D-8 Advance diffractometer with a $\mathrm{Co} k \alpha$ radiation, for crystalline phase detection between $20^{\circ}$ and $80^{\circ} 2 \theta$. JCPDSICDD standard files software was used to determine the phases. The IR spectra were recorded in a Nexus FT-IR 470 spectrometer in the range $1200-400 \mathrm{~cm}^{-1}$. The surface area was measured by a single-point BET procedure using nitrogen-argon adsorption at $-196^{\circ} \mathrm{C}$ with a $\mathrm{N}_{2} / \mathrm{Ar}$ ratio of 30/70 on a Micromeritics Model ASAP 2010. The images of scanning electron microscopy (SEM) were taken with a Hitachi S-500 microscope, operated at $20 \mathrm{keV}$ and $50 \mathrm{~mA}$. Chemical composition was determined by electron probe microanalysis on an EDX detector Kevex 7000 System. The temperature programmed reduction analysis (TPR) was carried out in a ThermoQuest TPD/TPR 1100 system using about $50 \mathrm{mg}$ of the sample in 8 vol\% $\mathrm{H}_{2} / 92 \mathrm{vol} \%$ Ar stream $(20 \mathrm{~mL} / \mathrm{min})$. The temperature was raised from room temperature to $120^{\circ} \mathrm{C}$ at a rate of $10^{\circ} \mathrm{C} / \mathrm{min}$, then holding it for $15 \mathrm{~min}$ to remove any adsorbed water, and raised again up to $1000^{\circ} \mathrm{C}$ for $2 \mathrm{~h}$.

The metal structures were hand manufactured with a form similar to the commercial packing Mellapak ${ }^{\circledR}$ of Sulzer (Figure 1(a)) [20], using strips of 316 stainless steel 100 mesh (Figures 1(b) and 1(c)). These structures were acid treated by $24 \mathrm{~h}$ at room temperature, to produce a rougher surface and thus improve catalyst adhesion. The incorporation of the perovskite-type oxide to the metal structure was carried out after evaporation at $80^{\circ} \mathrm{C}$; where the viscosity of the sample allows a better adherence. The immersion method was used to impreg-

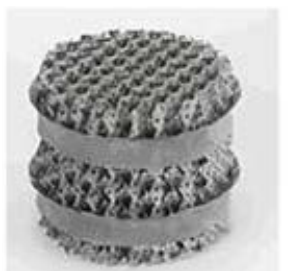

(a)

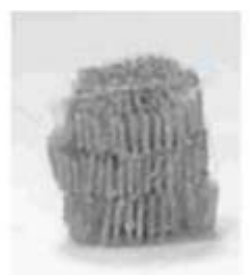

(b)

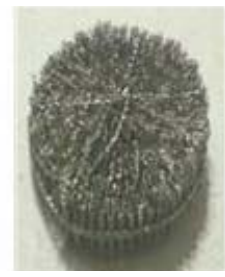

(c)
Figure 1. Metal structures (a) Mellapak packaging; (b) elaborated disks; (c) cross-section of the elaborated disks.

nate the metal structure with the perovskite-type oxide [21]. The structured catalyst was examined by scanning electronic microscopy (SEM).

\subsection{Activity Tests}

Catalytic tests were carried out in a fixed bed continuous flow system with a stainless steel reactor. Before the catalytic tests, the solids were reduced in $\mathrm{H}_{2}$ flow (50 $\mathrm{mL} / \mathrm{min}, \mathrm{T}=800^{\circ} \mathrm{C}, 8 \mathrm{~h}$ ). After reduction, the system was swept with Ar for $30 \mathrm{~min}$ and adjusted to reaction temperature. The reaction was carried out at atmospheric pressure between $600^{\circ} \mathrm{C}$ and $800^{\circ} \mathrm{C}, 24 \mathrm{Lh}^{-1} \cdot \mathrm{g}^{-1}$ hourly space velocitie with a molar ratio $\mathrm{CH}_{4} / \mathrm{O}_{2}=2$ for the combine reforming $[15,22]$. The water produced during reaction was condensed before passing the reactor outflow to the analyzing system, which consisted of an on-line gas chromatograph (Varian 3300) equipped with a TCD detector and provided with a Carbosieve SII 80/100 column. The $\mathrm{CH}_{4}$ and $\mathrm{CO}_{2}$ conversions are defined as the $\mathrm{CH}_{4}$ and $\mathrm{CO}_{2}$ converted per total amount of $\mathrm{CH}_{4}$ and $\mathrm{CO}_{2}$ fed, respectively. The total conversion $\left(\% \mathrm{X}_{\mathrm{i}}\right)$ was calculated according to Equation (5), from the values of areas (Ai) with nitrogen as a reference compound. The subscripts "s" and "e" refer to the flows in and out of the reactor, respectively.

$$
\begin{gathered}
\% \mathrm{X}_{\mathrm{i}}=\left(1-\frac{(\text { Ai } / \text { Aref }) \mathrm{s}}{(\text { Ai } / \text { Aref }) \mathrm{e}}\right) * 100 \\
\frac{\mathrm{H}_{2}}{\mathrm{CO}}=\frac{\mathrm{A}_{\mathrm{H}_{2}}}{\mathrm{~A}_{\mathrm{CO}}} \frac{\mathrm{f}\left(\mathrm{H}_{2} / \mathrm{N}_{2}\right)}{\mathrm{f}\left(\mathrm{CO} / \mathrm{N}_{2}\right)}
\end{gathered}
$$

The $\mathrm{H}_{2} / \mathrm{CO}$ molar ratio of the reaction products was determined using Equation (6), with the previously evaluated response factors, $\mathrm{f}$.

\section{Results and Discussion}

\subsection{Catalysts Characterization}

IR and XRD analyses were performed to verify formation of the perovskite-type structure. The IR spectra of 
the synthesized solids showed two broad bands characteristics of $\mathrm{ABO}_{3}$ mixed-oxide centered at 420 and 523 $\mathrm{cm}^{-1}$. Their positions are in good agreement with those reported in the literature $[15,18]$. The BET specific surface area of the synthesized perovskite, measure after calcined was $8 \mathrm{~m}^{2} / \mathrm{g}$. This value is typical for perovskites synthesized by the citrate sol-gel method [15]. The XRD pattern of synthesized perovskite shown in Figure 2, reveal the presence of crystalline $\mathrm{LaNiO}_{3}$. A notable change was observed in the XRD pattern of the reduced perovskite, as shown in Figure 3. After reduction, structural breakdown of the perovskite occur producing $\mathrm{Ni}^{0}$, $\mathrm{La}_{2} \mathrm{O}_{3}$ and $\mathrm{La}(\mathrm{OH})_{3}$.

The TPR profile of $\mathrm{LaNiO}_{3}$ perovskite-type oxide is shown in Figure 4. A first hydrogen consumption peak at $\sim 400^{\circ} \mathrm{C}$, attributed to reduction of $\mathrm{Ni}^{4+}$ species to $\mathrm{Ni}^{2+}$ is observed. The second hydrogen consumption peak appears at $\sim 500^{\circ} \mathrm{C}$, assigned to reduction of $\mathrm{Ni}^{2+}$ to $\mathrm{Ni}^{0}$, in agreement with a stepwise reduction.

The chemical composition of stainless steel mesh used to elaborate the metal structures, was determined by SEM coupled with EDX. The main components were Fe $(68 \%)$ and $\mathrm{Cr}(19 \%)$, followed by $\mathrm{Ni}(6 \%)$, Si (3\%), Al (3\%) and $\mathrm{Mn}(2 \%)$.

The SEM micrographs (Figures 5(a) and 5(b)) showed the roughness achieved by the acid treatment performed. Figure 5(c) shows an image of the $\mathrm{LaNiO}_{3}$ perovskite-type oxide on the structure, and Figure 5(d) shows an image of the powder perovskite-type oxide. A morphology that could be described as "flakes" was observed for supported and powder perovskites-type oxides. The adherence of the powder perovskites-type oxides on the metal structure was evaluated by immersing it in ethanol with ultrasonic bath for $15 \mathrm{~min}$, obtaining a $97 \%$ adherence.

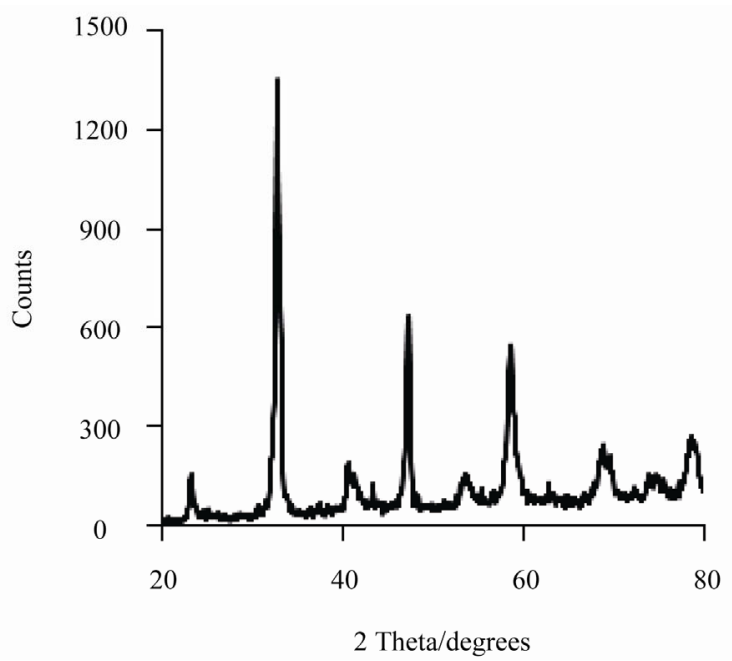

Figure 2. XRD pattern of synthesized $\mathrm{LaNiO}_{3}$.

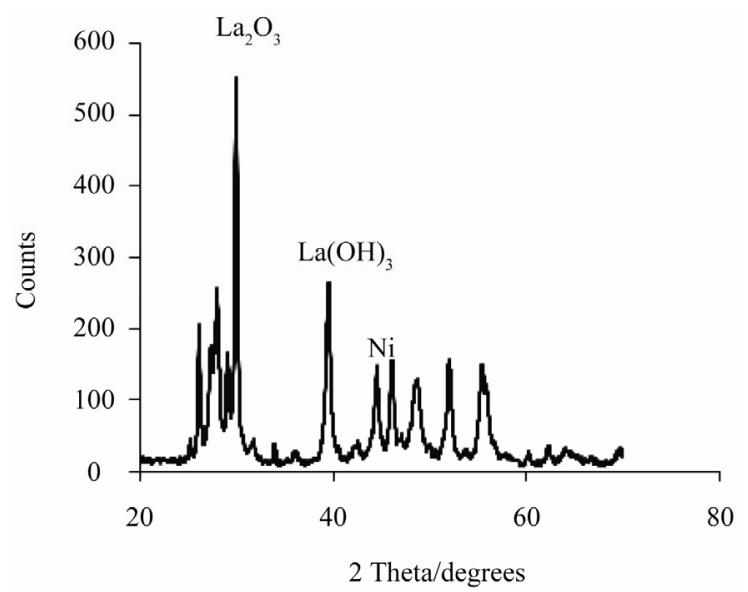

Figure 3. XRD pattern of $\mathrm{LaNiO}_{3}$ perovskite-type oxide after reduction under $\mathrm{H}_{2}$ stream.

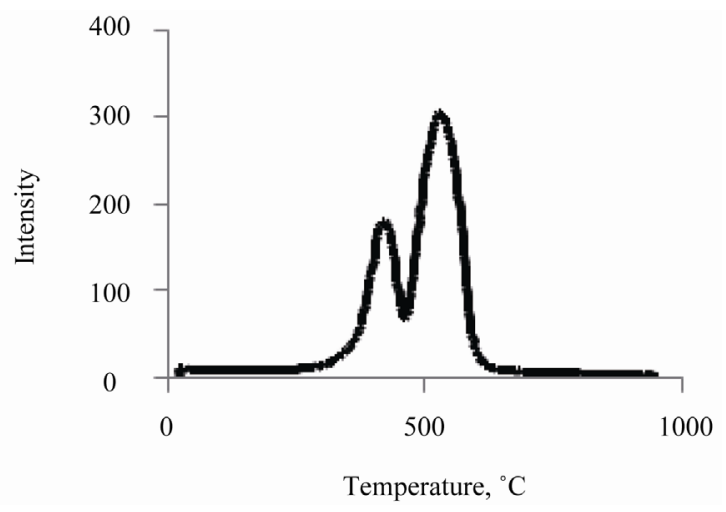

Figure 4. TPR profile of $\mathrm{LaNiO}_{3}$ perovskite-type oxide.

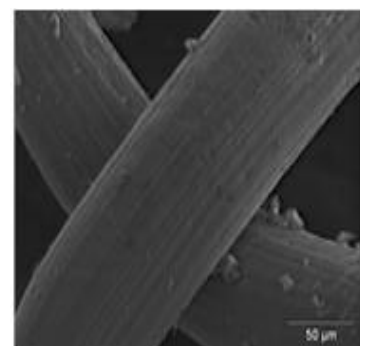

(a)

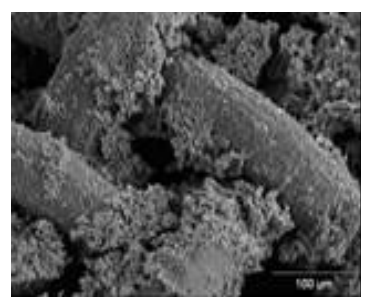

(c)

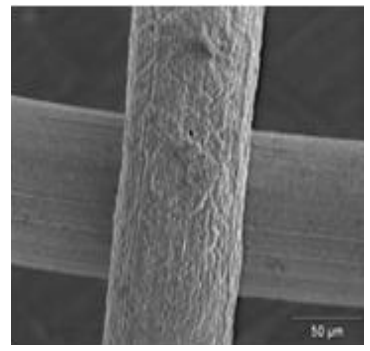

(b)

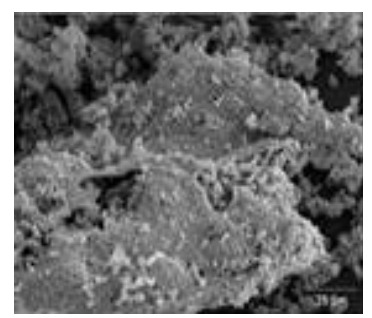

(d)
Figure 5. SEM Images (a) untreated stainless steel mesh (500×), (b) acid treated stainless steel mesh (500×), (c) perovskite supported on the mesh $(500 \times)$, (d) powder $\mathrm{LaNiO}_{3}$ perovskite $(800 \times)$. 


\subsection{Catalytic Tests}

The results of catalytic tests of the methane combined reforming with $\mathrm{CO}_{2}$ and $\mathrm{O}_{2}$ as a function of reaction temperature are shown in Table 1. The temperature was varied between $650^{\circ} \mathrm{C}$ and $850^{\circ} \mathrm{C}$, with intervals of $50^{\circ} \mathrm{C}$, using $300 \mathrm{mg}$ of $\mathrm{LaNiO}_{3}$ structured catalyst with $\mathrm{CH}_{4} / \mathrm{CO}_{2} / \mathrm{O}_{2}$ molar ratio of $2 / 1 / 1$. At $650^{\circ} \mathrm{C}$, after a $12 \mathrm{~h}$ induction period, a $67 \%$ methane conversion was obtained. At the beginning of the reaction, oxidation of metallic nickel could occur due to the high affinity between $\mathrm{Ni}$ and $\mathrm{O}_{2}$ [23]; which is then progressively reduced by the $\mathrm{H}_{2}$ produced in the reforming reaction, until stability is reached. $100 \%$ oxygen conversion was obtained during the entire tests, due to the fact that oxidation reactions are thermodynamically and kinetically favored [24]. An increase of methane and $\mathrm{CO}_{2}$ conversion with increasing temperature was obtained, as shown in Table 2. The consumption of methane by oxidation and $\mathrm{CO}_{2}$ reactions (Equation (4)) can explain the higher methane conversion observed compare to $\mathrm{CO}_{2}$ conversion, the last one being favored at temperature above $700^{\circ} \mathrm{C}$, due to its endothermic nature. $\mathrm{H}_{2} / \mathrm{CO}$ molar ratio in the reaction products remained around 1.4.

A second experiment at $750^{\circ} \mathrm{C}$ was performed varying the $\mathrm{CH}_{4} / \mathrm{CO}_{2}$ molar ratio in the input stream between 1 and 5, as shown in Table 2.

It is observed (Table 2) that the methane conversion increases with increasing the $\mathrm{CH}_{4} / \mathrm{CO}_{2}$ ratio, while a maximum for the $\mathrm{CO}_{2}$ conversion was attained at a $\mathrm{CH}_{4} / \mathrm{CO}_{2}$ ratio of 4 . A higher $\mathrm{H}_{2} / \mathrm{CO}$ ratio was also obtained for this $\mathrm{CH}_{4} / \mathrm{CO}_{2}$ ratio. Carbon formation without catalyst deactivation was observed during this experience. The carbon formed is presented as elongated filaments, as analyzed by SEM (Figure 6(a)), similar to those observed by Rynkowski et al. [25].

Table 1. $\mathrm{CH}_{4}$ and $\mathrm{CO}_{2}$ conversions and on $\mathrm{H}_{2} / \mathrm{CO}$ ratio as a function of temperature.

\begin{tabular}{cccc}
\hline Temperature ${ }^{\circ} \mathrm{C}$ & $\% \mathrm{X}_{\mathrm{CH}_{4}}$ & $\% \mathrm{X}_{\mathrm{CO}_{2}}$ & $\mathrm{H}_{2} / \mathrm{CO}$ \\
\hline 650 & 67 & 32 & 1.48 \\
700 & 68 & 46 & 1.39 \\
750 & 78 & 55 & 1.40 \\
800 & 91 & 73 & 1.44 \\
850 & 97 & 76 & 1.41 \\
\hline
\end{tabular}

$24 \mathrm{Lh}^{-1} \cdot \mathrm{g}^{-1} ; \mathrm{CH}_{4} / \mathrm{CO}_{2}=1 ; 300 \mathrm{mg}$ cat.

Table 2. Effect of the $\mathrm{CH}_{4} / \mathrm{CO}_{2}$ ratio in the input stream on $\mathrm{CH}_{4}$ and $\mathrm{CO}_{2}$ conversions and $\mathrm{H}_{2} / \mathrm{CO}$ ratio.

\begin{tabular}{cccc}
\hline $\mathrm{CH}_{4} / \mathrm{CO}_{2}$ & $\% \mathrm{X}_{\mathrm{CH}_{4}}$ & $\% \mathrm{X}_{\mathrm{CO}_{2}}$ & $\mathrm{H}_{2} / \mathrm{CO}$ \\
\hline 1 & 72 & 40 & 1.08 \\
2 & 81 & 52 & 1.47 \\
4 & 89 & 61 & 1.92 \\
5 & 91 & 52 & 1.89 \\
\hline
\end{tabular}

$24 \mathrm{Lh}^{-1} \cdot \mathrm{g}^{-1} ; 750{ }^{\circ} \mathrm{C} ; 300 \mathrm{mg}$ cat.

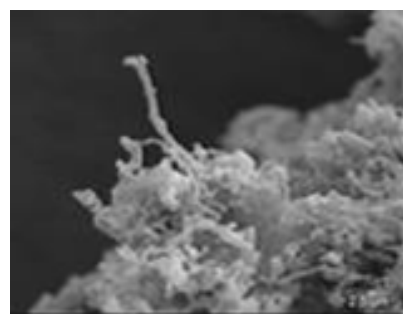

(a)

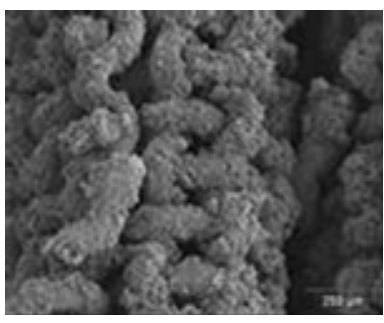

(b)
Figure 6. SEM Images of the catalysts after reaction: (a) $8000 \times$, (b) $100 \times$.

Figure 5(b) shows an image of the structured catalyst after reaction; when it is compared to the catalyst before reaction (Figure 5(c)) it can be observed that the structure is more opaque and that it has a layer of a denser solid. The solid layer coating the structure after reaction can be attributed to formation of lanthanum dioxomonocarbonate $\left(\mathrm{La}_{2} \mathrm{O}_{2} \mathrm{CO}_{3}\right)$, whose characteristic lines were observed in the XRD pattern of the catalyst after reaction (Figure 7).

The combined methane reforming with $\mathrm{CO}_{2}$ and $\mathrm{O}_{2}$, involves a complex set of reactions, where the predominance of a given reaction depends on the catalyst and reaction conditions. In addition to the reactions 1 to 4 , the following reactions may occur:

$$
\begin{array}{ll}
\mathrm{CO}+\mathrm{H}_{2} \longrightarrow \mathrm{CO}+\mathrm{H}_{2} \mathrm{O} & \text { WGS reverse } \\
2 \mathrm{CO} \longrightarrow \mathrm{C}+\mathrm{CO}_{2} & \text { Boudouard reaction } \\
\mathrm{CH}_{4} \longrightarrow \mathrm{C}+2 \mathrm{H}_{2} & \text { Methane cracking }
\end{array}
$$

Several possibilities have to be considered to analyze the observed results:

In the case of $\mathrm{CH}_{4} / \mathrm{CO}_{2}=1$ ratio, the proportion of $\mathrm{CO}_{2}$ in the input stream to the reactor is higher than the oxygen proportion $\left(\mathrm{CH}_{4} / \mathrm{O}_{2}=2\right)$. However, combustion reactions occur (Equations (2) and (3)) because they are kinetic and thermodynamically favored. The reforming of methane with $\mathrm{CO}_{2}$ (Equation (4)), also is promoted due to the high temperature and high concentration of $\mathrm{CO}_{2}$. The reaction conditions also favor the reverse water gas

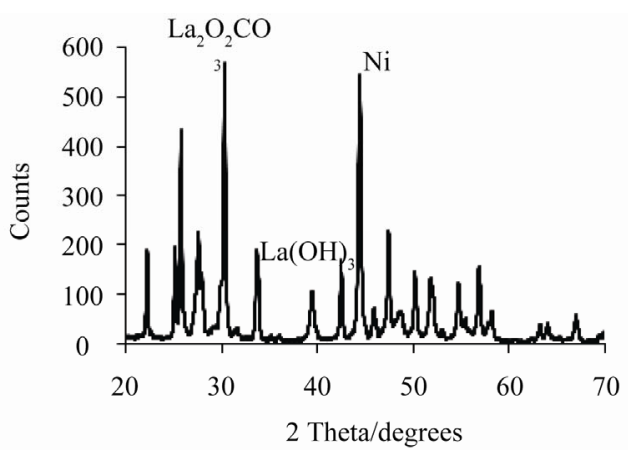

Figure 7. XRD pattern of after reaction catalysts. 
shift reaction (Equation (7)) and methane cracking (Equation (9)). Thus if under these conditions, reactions $(2)+(3)+(4)+(7)+(9)$ are predominant, the overall reaction can be represented by Equation (10), with a $\mathrm{H}_{2} / \mathrm{CO}=1.25$ ratio, comparable to the experimental value obtained.

$$
4 \mathrm{CH}_{4}+5 / 2 \mathrm{O}_{2}+\mathrm{CO}_{2} \longrightarrow 4 \mathrm{CO}+5 \mathrm{H}_{2}+3 \mathrm{H}_{2} \mathrm{O}+\mathrm{C}
$$

For the $\mathrm{CH}_{4} / \mathrm{O}_{2}=2$ molar ratio, the value obtained for the $\mathrm{H}_{2} / \mathrm{CO}$ ratio in the products suggests the combination of reactions $(3)+(4)+(1)+(7)+(8)$ to give the global reaction represented by Equation (11). $\mathrm{The}_{2} / \mathrm{CO}=1.47$ ratio obtained is comparable to the $\mathrm{H}_{2} / \mathrm{CO}$ ratio according to the Equation (11).

$$
4 \mathrm{CH}_{4}+2 \mathrm{O}_{2}+\mathrm{CO}_{2} \longrightarrow 4 \mathrm{CO}+6 \mathrm{H}_{2}+2 \mathrm{H}_{2} \mathrm{O}+\mathrm{C}
$$

For $\mathrm{CH}_{4} / \mathrm{CO}_{2}=4$ ratio, the highest $\mathrm{H}_{2} / \mathrm{CO}$ molar ratio (1.92) was obtained. Under these conditions the occurrence of Reactions (1-4) and (7-8) are favored, giving rise to the overall reaction represented by Equation (12). The $\mathrm{H}_{2} / \mathrm{CO}$ ratio for this Equation is 2, in good agreement with 1.92 obtained experimentally.

$$
4 \mathrm{CH}_{4}+5 / 2 \mathrm{O}_{2} \longrightarrow 3 \mathrm{CO}+6 \mathrm{H}_{2}+2 \mathrm{H}_{2} \mathrm{O}+\mathrm{C}
$$

The $\mathrm{CH}_{4} / \mathrm{CO}_{2}$ ratio equal to 4 implies a higher amount of $\mathrm{CH}_{4}$ compared to $\mathrm{CO}_{2}$. In this case the oxygen proportion is lower than that of $\mathrm{CO}_{2}$, which can favoured oxidation reactions producing a higher proportion of $\mathrm{H}_{2} \mathrm{O}$ and $\mathrm{CO}_{2}$. As a consequence, the contribution of Reactions (1) and (4) is stronger, giving raise to a higher $\mathrm{H}_{2} / \mathrm{CO}$ ratio in the reaction products. The molar ratio for $4 / 1 / 2 \mathrm{CH}_{4} / \mathrm{CO}_{2} / \mathrm{O}_{2}$ was selected to compare the performance of the structured catalyst with respect to the powder catalyst.

\subsection{Structured and Powder Catalytic Tests}

Results of the catalytic tests for both structured and powder catalysts are shown in Figure 8, at $750^{\circ} \mathrm{C}$ and $\mathrm{CH}_{4} / \mathrm{CO}_{2} / \mathrm{O}_{2}$ molar ratios of $4 / 1 / 2$. A significant improvement in the conversion of $\mathrm{CH}_{4}$ and $\mathrm{CO}_{2}$ over the structured catalyst was obtained; in addition, the induction period required by the powder catalyst was not required on the structured catalyst. During the first $20 \mathrm{~h}$ of time on stream, negative conversion values of $\mathrm{CO}_{2}$ were obtained, because proportion of $\mathrm{CO}_{2}$ produced from total combustion (Equation (3)) is higher than the consumed $\mathrm{CO}_{2}$. On the other hand, $\mathrm{H}_{2} / \mathrm{CO}$ molar ratio in reaction products was 1.94; this value is higher than the $\mathrm{H}_{2} / \mathrm{CO}$ ratio obtained with the powder catalyst, which was 1.64.

The purpose of the metal structure is to take advantage of improving heat transfer in the catalytic bed. Thus, the increase of catalytic activity can be attributed to better

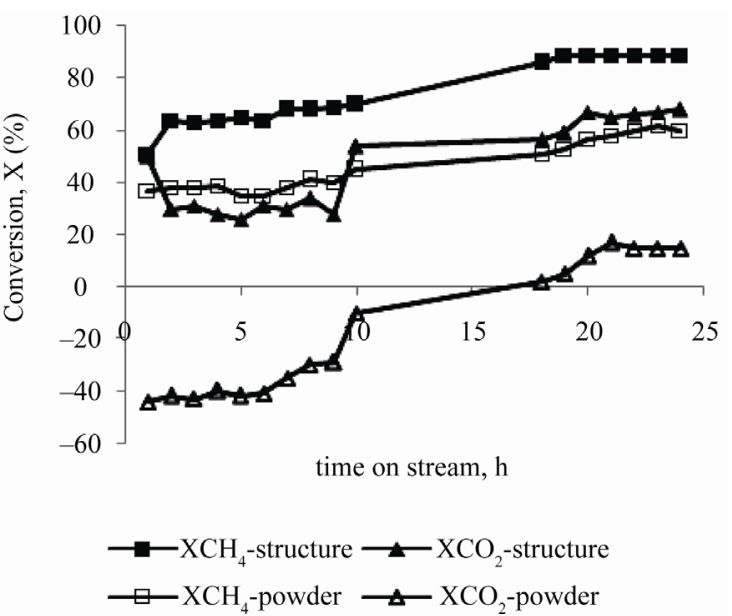

Figure 8. $\mathrm{CH}_{4}$ and $\mathrm{CO}_{2}$ conversions of structured and powder catalysts.

employment by endothermic reactions such as reforming of methane with $\mathrm{CO}_{2}$ and $\mathrm{H}_{2} \mathrm{O}$ of the heat released by exothermic reactions. Moreover, the shape of the structure could allow a greater contact between the catalyst and reagents.

The catalytic stability of the structured catalyst was evaluated during 52 hours on stream. Results are shown in Figure 9; after 24 hours the catalyst seems to reach steady-state conditions, the conversion of methane and $\mathrm{CO}_{2}$ remain in average values of 90 and $60 \%$ respectively, and the $\mathrm{H}_{2} / \mathrm{CO}$ ratio in reaction products was close to 2 . The catalyst stability despite carbon formation has been attributed to the formation of $\mathrm{La}_{2} \mathrm{O}_{2} \mathrm{CO}_{3}$ during the reaction [26], according to XRD pattern of the solid after reaction such as shown in Figure 7.

\section{Conclusions}

The $\mathrm{LaNiO}_{3}$ perovskite-type oxide was obtained as a

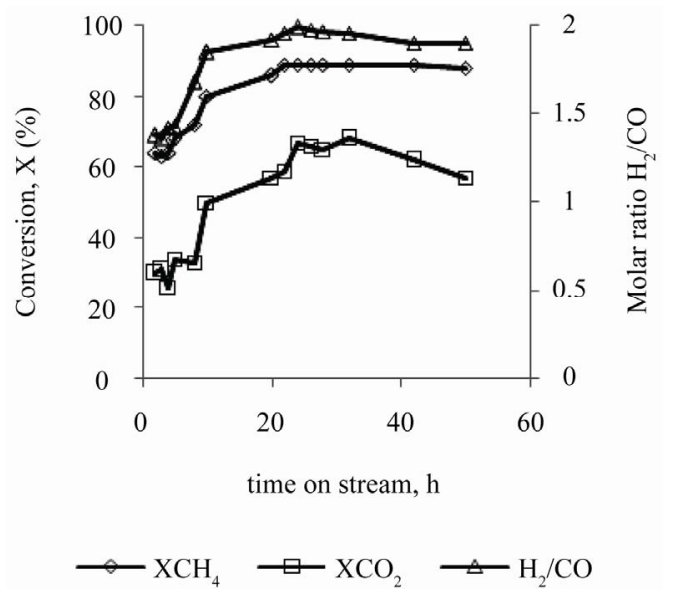

Figure 9. Catalytic stability test of structured catalyst. 
pure highly crystalline phase, which after reduction presented major structural changes, giving rise to well disperse nickel metallic particles on a lanthanum oxide and hydroxide matrix.

An adherence of $97 \%$ of the perovskite-type oxide to the metallic surface was achieved by means of the acid treatment carried out to the metal structure the immersion procedure used in the preparation of the structured catalyst.

The system studied is complex and involves several reactions that depend largely on the composition of the feed to reactor, as well as of the catalyst and the operational reaction conditions employed.

A positive influence of the metallic structure in the combined methane reforming reaction with $\mathrm{CO}_{2}-\mathrm{O}_{2}$ was observed. The stability of the structured catalyst was higher compared to that observed for the powder catalyst. In addition, no induction period was required for the structured catalyst.

\section{Acknowledgements}

The authors are grateful to CDCH UCV for the financial support through project No 08-00-6607-2006.

\section{References}

[1] L. Profeti, E. Ticianelli and E. Assaf, " $\mathrm{Co} / \mathrm{Al}_{2} \mathrm{O}_{3}$ Catalysts Promoted with Noble Metals for Production of Hydrogen by Methane Steam Reforming," Fuel, Vol. 87, No. 10-11, 2008, pp. 2076-2081. doi:10.1016/j.fuel.2007.10.015

[2] A. Iulianelli, G. Manzolini, S. Campanari, T. Longo, S. Liguori and A. Basile, " $\mathrm{H}_{2}$ Production by Low Pressure Methane Steam Reforming in a Pd-Ag Membrane Reactor over a Ni-Based Catalyst: Experimental and Modeling," International Journal of Hydrogen Energy, Vol. 35, No. 20, 2010, pp. 11514-11524.

[3] X. Song and Z. Guo, "Technologies for Direct Production of Flexible $\mathrm{H}_{2} / \mathrm{CO}$ Synthesis Gas," Energy Conversion and Management, Vol. 47, No. 5, 2006, pp. 560-569. doi:10.1016/j.enconman.2005.05.012

[4] G. Wang and M. Coppens, "Rational Design of Hierarchically Structured Porous Catalyst for Autothermal Reforming of Methane," Chemical Engineering Science, Vol. 65, No. 7, 2010, pp. 2344-2351. doi:10.1016/j.ces.2009.09.079

[5] A. De Souza, L. Lins, N. Filho and C. De Abreu, "Catalytic Activity Evaluation for Hydrogen Production via Autothermal Reforming of Methane," Catalysis Today, Vol. 149, No. 3-4, 2010, pp. 413-417. doi:10.1016/j.cattod.2009.06.003

[6] W. Chen, M. Lin, J. Lu, Y. Chao and T. Leu, "Thermodynamic Analysis of Hydrogen Production from Methane via Autothermal Reforming and Partial Oxidation Followed by Water Gas Shift Reaction," International Jour- nal of Hydrogen Energy, Vol. 35, No. 21, 2010, pp. 11787-11797. doi:10.1016/j.ijhydene.2010.08.126

[7] R. Ganesh, D. Bhaskar and R. Ajit, "Thermodynamic Study of Combining Chemical Looping Combustion and Combined Reforming of Propane," Fuel, Vol. 89, No. 10, 2010, pp. 3141-3146. doi:10.1016/j.fuel.2010.05.029

[8] Q. Jing and X. Zheng, "Combined Catalytic Partial Oxidation and $\mathrm{CO}_{2}$ Reforming of Methane over $\mathrm{ZrO}_{2}$-Modified $\mathrm{Ni} / \mathrm{SiO}_{2}$ Catalysts Using Fluidized-Bed Reactor," Energy, Vol. 31, No. 12, 2006, pp. 2184-2192. doi:10.1016/j.energy.2005.07.005

[9] J. Múnera, C. Carrara, L. Cornaglia and E. Lombardo, "Combined Oxidation and Reforming of Methane to Produce Pure $\mathrm{H}_{2}$ in a Membrane Reactor," Chemical Engineering Journal, Vol. 161, No. 1-2, 2010, pp. 204-211. doi:10.1016/j.cej.2010.04.022

[10] J. Gao, Z. Hou, X. Liu, Y. Zeng, M. Luo and X. Zheng, "Methane Autothermal Reforming with $\mathrm{CO}_{2}$ and $\mathrm{O}_{2}$ to Synthesis Gas at the Boundary between $\mathrm{Ni}$ and $\mathrm{ZrO}_{2}$," International Journal of Hydrogen Energy, Vol. 34, No. 9, 2009, pp. 3734-3742. doi:10.1016/j.ijhydene.2009.02.074

[11] J. Łojewska, A. Kołodziej, T. Łojewski, R. Kapica and J. Tyczkowski, "Structured Cobalt Oxide Catalyst for VOC Combustion. Part I: Catalytic and Engineering Correlations," Applied Catalysis A: General, Vol. 366, No. 1, 2009, pp. 206-211. doi:10.1016/j.apcata.2009.07.006

[12] A. Kołodziej, W. Krajewski and A. Dubis, "Alternative Solution for Strongly Exothermal Catalytic Reactions: A New Metal-Structured Catalyst Carrier," Catalysis Today, Vol. 69, No. 1-4, 2001, pp. 115-120. doi:10.1016/S0920-5861(01)00361-3

[13] J. Lojewska, A. Kolodziej, R. Kapica, A. Knapik and J. Tyczkowski, "In Search for Active Non-Precious Metal Catalyst for VOC Combustion: Evaluation of Plasma Deposited $\mathrm{Co}$ and $\mathrm{Co} / \mathrm{Cu}$ Oxide Catalysts on Metallic Structured Carriers," Catalysis Today, Vol. 147, Suppl. 1, 2009, pp. S94-S98. doi:10.1016/j.cattod.2009.07.021

[14] R. Pereñíguez, V. González-DelaCruz, J. Holgado and A. Caballero, "Synthesis and Characterization of a $\mathrm{LaNiO}_{3}$ Perovskite as Precursor for Methane Reforming Reactions Catalysts," Applied Catalysis B: Environmental, Vol. 93, No. 3-4, 2010, pp. 346-353. doi:10.1016/j.apcatb.2009.09.040

[15] M. Goldwasser, M. Rivas, M. Lugo, E. Pietri, M. Pérez-Zurita, M. Cubeiro, A. Griboval-Constant and G. Leclercq, "Combined Methane Reforming in Presence of $\mathrm{CO}_{2}$ and $\mathrm{O}_{2}$ over $\mathrm{LaFe}_{1-\mathrm{x}} \mathrm{Co}_{\mathrm{x}} \mathrm{O}_{3}$ Mixed-Oxide Peorvskites as Catalysts Precursors," Catalysis Today, Vol. 107-108, 2008, pp. 106-113. doi:10.1016/j.cattod.2005.07.073

[16] G. Sierra Gallego, J. Gallego Marín, C. Batiot-Dupeyrat, J. Barrault and F. Mondragón, "Influence of $\mathrm{Pr}$ and Ce in Dry Methane Reforming Catalysts Produced from $\mathrm{La}_{1-x}$ $\mathrm{A}_{\mathrm{x}} \mathrm{NiO}_{3-\delta}$ Perovskites," Applied Catalysis A: General, Vol. 369, No. 1-2, 2009, pp. 97-103.

[17] K. Urasaki, Y. Sekine, S. Kawabe, E. Kikuchi and M. Matsukata, "Catalytic Activities and Coking Resistance of Ni/Perovskites in Steam Reforming of Methane," Ap- 
plied Catalysis A: General, Vol. 286, No. 1, 2005, pp. 23-29. doi:10.1016/j.apcata.2005.02.020

[18] M. Goldwasser, M. Rivas, E. Pietri, M. Pérez-Zurita, M. Cubeiro, L. Gingembre, L. Leclercq and G. Leclercq, "Perovskites as Catalysts Precursors: $\mathrm{CO}_{2}$ Reforming of $\mathrm{CH}_{4}$ on $\mathrm{Ln}_{1-\mathrm{x}} \mathrm{Ca}_{\mathrm{x}} \mathrm{Ru}_{0.8} \mathrm{Ni}_{0.2} \mathrm{O}_{3}(\mathrm{Ln}=\mathrm{La}, \mathrm{Sn}, \mathrm{Nd})$," Applied Catalysis A: General, Vol. 255, No. 1-2, 2003, pp. 45-57. doi:10.1016/S0926-860X(03)00643-4

[19] A. Majid, J. Tunney, S. Argue, D. Wang, M. Post and J. Margeson, "Preparation of $\mathrm{SrFeO}_{2.85}$ Perovskite Using a Citric Acid Assisted Pechini-Type Method," Journal of Alloy and Compounds, Vol. 398, No. 1-2, 2005, pp. 4854. doi:10.1016/j.jallcom.2005.02.023

[20] P. Suess and L. Spiegel, "Hold-up of Mellapak Structured Packings," Chemical Engineering and Processing, Vol. 31, 1992, pp. 119-124. doi:10.1016/0255-2701(92)85005-M

[21] V. Meille, "Review on Methods to Deposit Catalysts on Structured Surfaces," Applied Catalysis A: General, Vol. 315, 2006, pp. 1-17. doi:10.1016/j.apcata.2006.08.031

[22] N. Saidina Amin and T. Chun Yaw, "Thermodynamic Equilibrium Analysis of Combined Carbon Dioxide Reforming with Partial Oxidation of Methane to Syngas," International Journal of Hydrogen Energy, Vol. 32, No.
12, 2007, pp. 1789-1798. doi:10.1016/j.ijhydene.2006.12.004

[23] M. Simeone, L. Salemme, D. Scognamiglio, C. Allouis and G. Volpicelli, "Effect of Water Addition and Stoichiometry Variations on Temperature Profiles in an Autothermal Methane Reforming Reactor with Ni Catalyst," International Journal of Hydrogen Energy, Vol. 33, No. 4, 2008, pp. 1252-1261. doi:10.1016/j.ijhydene.2007.12.034

[24] O. Lian Ding and S. Hwa Chan, "Water-Gas Shift Assisted Autothermal Reforming of Methane Gas-Transient and Cold Start Studies," International Journal of Hydrogen Energy, Vol. 34, No. 1, 2009, pp. 270-284. doi:10.1016/j.ijhydene.2008.09.079

[25] J. Rynkowski, P. Samulkiewicz, A. Ladavos and P. Pomonis, "Catalytic Performance of Reduced $\mathrm{La}_{2-\mathrm{x}} \mathrm{Sr}_{\mathrm{x}} \mathrm{NiO}_{4}$ Perovskite-Like Oxides for $\mathrm{CO}_{2}$ Reforming of $\mathrm{CH}_{4}$," Applied Catalysis A: General, Vol. 263, No. 1, 2004, pp. 1-9. doi:10.1016/j.apcata.2003.11.022

[26] A. Slagtern, Y. Schuurman, C. Leclercq, X. Verykios and C. Mirodatos, "Specific Features Concerning the Mechanism of Methane Reforming by Carbon Dioxide over $\mathrm{Ni} / \mathrm{La}_{2} \mathrm{O}_{3}$ Catalyst," Journal of Catalysis, Vol. 172, No. 1, 1997, pp. 118-126. doi:10.1006/jcat.1997.1823 